\title{
Ultradźwiękowa plastyka ciała rzęskowego w terapii jaskry opornej - obserwacje średnioterminowe
}

\author{
Ultrasound ciliary plasty in refractory glaucoma treatment - a medium-term follow-up study
}

\author{
Bartłomiej Bolek, Edward Wylęgała \\ Katedra i Oddział Kliniczny Okulistyki, Wydział Nauk Medycznych w Zabrzu, \\ Śląski Uniwersytet Medyczny w Katowicach, Okręgowy Szpital Kolejowy w Katowicach \\ Kierownik Ośrodka: prof. dr hab. n. med. Edward Wylęgała
}

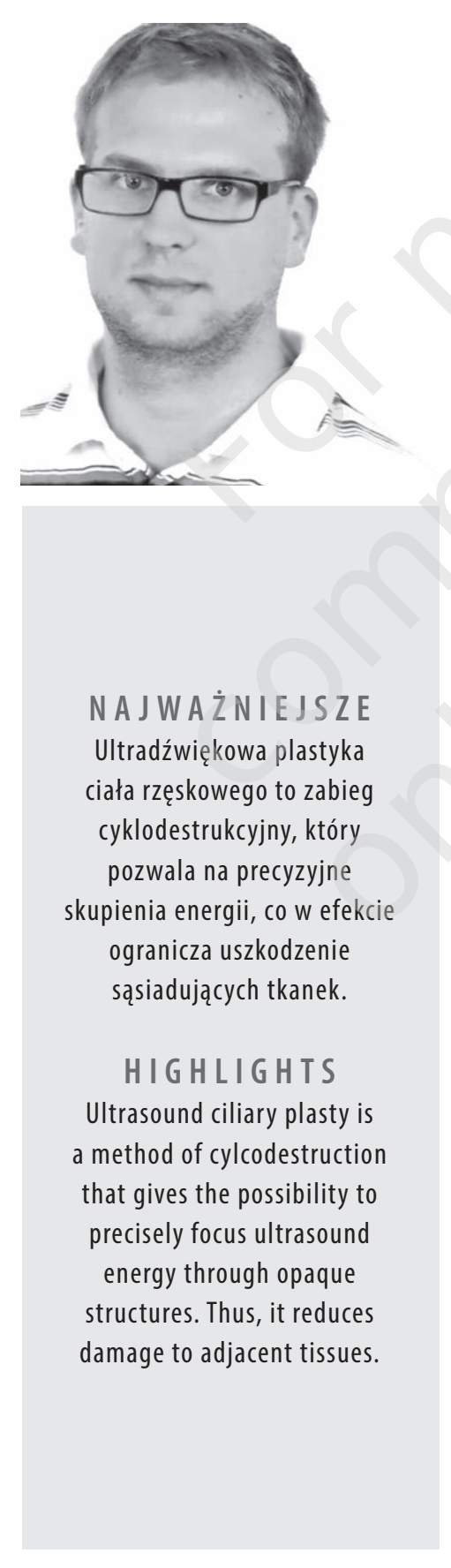

\section{STRESZCZENIE}

Cel pracy: Ocena rocznej skuteczności i bezpieczeństwa zabiegu ultradźwiękowej plastyki ciała rzęskowego w jaskrze opornej.

Material i metody: 57 pacjentów ( $37 \mathrm{~K}, 20$ M, średnia wieku: 67,6 roku) z jaskrą pierwotną i wtórną otwartego kąta poddano zabiegowi. Kryteriami włączenia były: wiek powyżej 18. r.ż., niekontrolowana jaskra otwartego kąta (ciśnienie wewnątrzgałkowe $>21 \mathrm{mmHg}$ ), przeciwwskazania do zabiegu klasycznego, nietolerancja leków. Kryteriami wyłączenia były: ciąża, niepełnoletniość, ciśnienie wewnątrzgałkowe $>30 \mathrm{mmHg}$, jaskra zamykającego się kąta lub neowaskularna. Pełne badanie okulistyczne przeprowadzono przed zabiegiem oraz dzień, tydzień, miesiąc, 3 miesiące, 6 miesięcy i 12 miesięcy po zabiegu. Ciśnienie wewnątrzgałkowe badano za pomocą tonometrii aplanacyjnej Goldmanna. Za skuteczność leczenia przyjęto obniżenie ciśnienia wewnątrzgałkowego o $20 \%$ lub o ponad $5 \mathrm{mmHg}$ w stosunku do pomiaru wyjściowego (sukces częściowy) oraz całkowite odstawienie leków przeciwjaskrowych (sukces całkowity).

Wyniki: Średnia wartość ciśnienia wewnątrzgałkowego została obniżona o 26,9\% na ostatniej wizycie w porównaniu z wartością sprzed operacji. Sukces częściowy uzyskano w przypadku $87,7 \%$ oczu, a sukces całkowity w przypadku $12,3 \%$ oczu. Średnia liczba leków przeciwjaskrowych wyniosła odpowiednio: $4,0 \pm 0,9,0,9 \pm 1,1,0,9 \pm 1,1,1,1 \pm 1,1,1,8 \pm 1,4,2,1 \pm 1,4,2,4 \pm 1,4(\mathrm{p}<0,001$ dla wszystkich wartości). Średnia wartość najlepszej skorygowanej ostrości wzroku \pm SD wyniosła odpowiednio: $0,37 \pm 0,46,0,47 \pm 0,45(\mathrm{p}=0,003), 0,46$ $\pm 0,45(\mathrm{p}=0,004), 0,31 \pm 0,37(\mathrm{p}=0,151), 0,36 \pm 0,45(\mathrm{p}=0,880), 0,39 \pm 0,47$ $(\mathrm{p}=0,504)$. Nie odnotowano poważnych powikłań poza odłączeniem naczyniówki (5,3\%) i obrzękiem plamki (3,5\%).

Wnioski: Ultradźwiękowa plastyka ciała rzęskowego jest metodą skuteczną i bezpieczną w obserwacji średnioterminowej. Dalsze badania na większej grupie powinny być prowadzone w dłuższym okresie obserwacji.

Słowa kluczowe: cyklodestrukcja, jaskra oporna, ultradźwięki, ciśnienie wewnątrzgałkowe, ultradźwiękowa plastyka ciała rzęskowego 


\section{ABSTRACT}

Objectives: To assess the efficacy and safety of ultrasound ciliary plasty (UCP) for treating refractory glaucoma during one year follow-up.

Material and methods: A total of 57 patients (37 F, 20 M; mean age: 67.6 years) with primary and secondary refractory glaucoma were enrolled to undergo UCP. The inclusion criteria for the study were: $\geq 18$ years, uncontrolled open-angle glaucoma (IOP $>21 \mathrm{mmHg}$ ), contraindication to incisional glaucoma surgery, intolerance to glaucoma medications despite well-controlled IOP. The exclusion criteria were: pregnancy, age $<18$ years, IOP $>30 \mathrm{mmHg}$, angle-closure glaucoma and neovascular glaucoma. Complete ophthalmic examinations were performed preoperatively and as well as 1 week and 1,3 , 6,12 months postoperatively. An IOP reduction of $20 \%$ or $>5 \mathrm{mmHg}$ as compared to the baseline value was considered as successful treatment. Complete success was defined as cessation of antiglaucoma medications.

Results: The mean IOP at the last follow-up was reduced by $26.9 \%$. The success rate was $87.7 \%$ and the complete success rate was $12.3 \%$. The mean \pm SD values of the number of antiglaucoma medications were: $4.0 \pm 0.9,0.9 \pm 1.1$, $0.9 \pm 1.1,1.1 \pm 1.1,1.8 \pm 1.4,2.1 \pm 1.4,2.4 \pm 1.4$ ( $\mathrm{p}<0.001$ for all values), respectively. The best-corrected $\log$ MAR visual acuities were: $0.37 \pm 0.46,0.47$ $\pm 0.45(\mathrm{p}=0.003), 0.46 \pm 0.45(\mathrm{p}=0.004), 0.31 \pm 0.37(\mathrm{p}=0.151), 0.36 \pm 0.45$ $(\mathrm{p}=0.880), 0.39 \pm 0.47(\mathrm{p}=0.504)$, respectively. Following the procedure, choroid detachment was observed in three patients (5.3\%) and macular in two patients $(3.5 \%)$. No other major intraoperative or postoperative complications occurred.

Conclusion: Ultrasound ciliary plasty is a safe and well-tolerated procedure in medium-term follow-up. Further studies with a larger group of patients and longer follow-up are needed to confirm these results.

Key words: cyclodestruction, glaucoma, high-intensity focused ultrasound, intraocular pressure, ultrasound ciliary plasty

\section{WSTĘP}

Zabiegi cyklodestrukcyjne stosowane są głównie w zaawansowanych postaciach jaskry, w przypadku gdy wcześniej wdrożone metody leczenia zachowawczego lub chirurgicznego nie dają oczekiwanych rezultatów.

Obniżenie ciśnienia wewnątrzgałkowego (CWG) poprzez zmniejszenie produkcji cieczy wodnistej uzyskuje się poprzez częściowe uszkodzenie nabłonka niebarwnikowego ciała rzęskowego. Wykorzystuje się mechanizmy destrukcyjne fotokoagulacji, krioterapii czy ultradźwięków.

Ultradźwiękowa plastyka ciała rzęskowego (UCP, ultrasound ciliary plasty) w porównaniu z powszechnie stosowanymi zabiegami cyklodestrukcyjnymi pozwala na precyzyjne skupienia energii, bez niekontrolowanej absorpcji, na pożądanej gębokości oraz powierzchni. W efekcie ogranicza uszkodzenie sąsiadujących tkanek. Pierwsze prace nad ultradźwiękową cyklokoagulacją powstały w ubiegłym stuleciu. Ze względu na powikłania związane z uszkodzeniem okolicznych tkanek dalszych prac nie kontynuowano. Po- prawiona metoda i unowocześnione urządzenie EyeOP1 ${ }^{\oplus}$ zostały wprowadzone do komercyjnego użytku w 2015 r. Wykorzystuje ono ultradźwięki o wysokiej intensywności, co znacznie poprawiło selektywność w stosunku do tkanki docelowej. Pierwsze prace, opublikowane przez pioniera tej metody Aptela, pojawiły się w latach 2010 i 2011 [1-3].

\section{CEL PRACY}

Celem pracy jest ocena skuteczności i bezpieczeństwa zabiegu UCP w terapii jaskry opornej w okresie rocznej obserwacji.

\section{MATERIAŁ I METODY}

Prospektywne badanie zostało przeprowadzone za zgodą Komisji Bioetycznej przy Śląskim Uniwersytecie Medycznym (nr decyzji KNW/0022/KB1/78/18) według zaleceń Deklaracji Helsińskiej. 
57 pacjentów z jaskrą pierwotną i wtórną otwartego kąta zostało poddanych zabiegowi UCP. Grupę badaną stanowiło 37 kobiet oraz 20 mężczyzn, średnia wieku wynosiła 67,6 roku (od 26 do 82 lat). Kryteriami włączenia do badania były: pełnoletniość (wiek powyżej 18. r.ż.), niekontrolowana jaskra otwartego kąta (definiowana jako CWG $>21 \mathrm{mmHg}$ pomimo maksymalnego tolerowanego leczenia farmakologicznego), przeciwwskazania do klasycznego zabiegu przeciwjaskrowego, nietolerancja leków przeciwjaskrowych. Kryteriami wyłączenia z badania były: ciąża, niepełnoletniość pacjentów, CWG < 30 mmHg, jaskra zamykającego się kąta, jaskra neowaskularna. Wcześniejsze operacje przeciwjaskrowe nie były kryterium wykluczającym z badania. Szczegółowa charakterystyka pacjentów została przedstawiona w tabeli 1 .
Badanie okulistyczne przeprowadzono w lampie szczelinowej CSO (Costruzione Strumenti Oftalmici, Florence, Italy) z wykonaniem dokumentacji fotograficznej.

Za skuteczność leczenia przyjęto obniżenie CWG o 20\% lub o ponad $5 \mathrm{mmHg}$ w stosunku do pomiaru wyjściowego (sukces częściowy) oraz całkowite odstawienie leków przeciwjaskrowych (sukces całkowity).

W przypadku nieuzyskania docelowego CWG pacjenci byli poddawani dodatkowym zabiegom przeciwjaskrowym. W obecnym badaniu przeprowadzano ponowną ultradźwiękową plastykę ciała rzęskowego lub przeztwardówkową cyklofotokoagulację za pomocą lasera diodowego (TSCP, transscleral cyclophotocoagulation). Metoda operacyjna była wybierana w zależności od stanu klinicznego pacjenta.

\section{TABELA $(1$}

\section{Średnie ciśnienie wewnątrzgałkowe, średnia liczba leków przeciwjaskrowych oraz procentowe obniżenie CWG} przed zabiegiem UCP i po nim w rocznym okresie obserwacji.

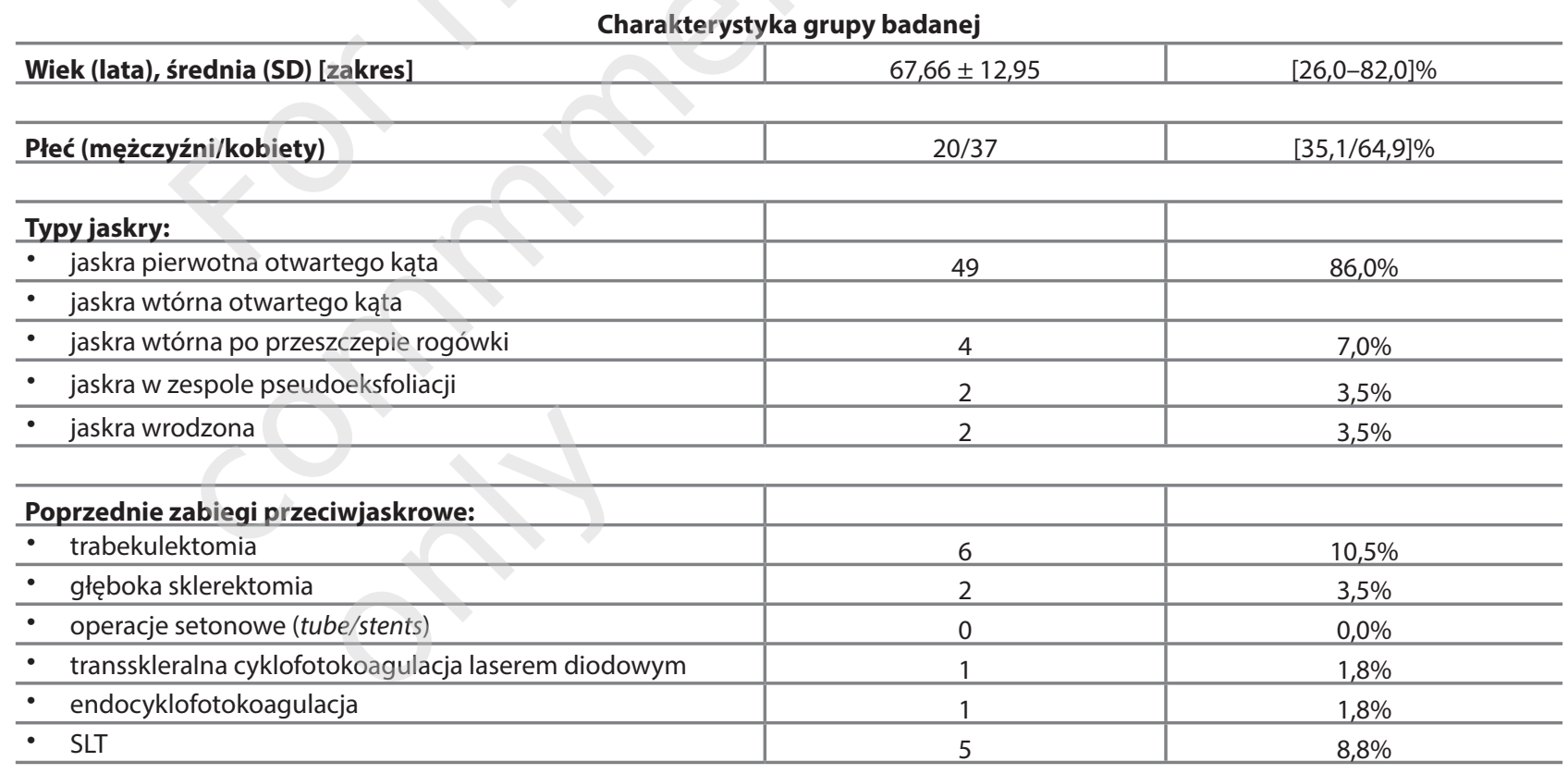

\begin{tabular}{l|c|c}
\hline Status soczewki: & & \\
\hline$\quad$ soczewkowe & 33 & $57,9 \%$ \\
\hline rzekomosoczewkowe & 23 & $40,4 \%$ \\
\hline bezsoczewkowe & 1 & $1,8 \%$
\end{tabular}

Pełne badanie okulistyczne z pomiarem CWG, liczbą leków przeciwjaskrowych i najlepszą skorygowaną ostrością wzroku (BCVA, best corrected visual acuity) zostało przeprowadzone przed zabiegiem UCP oraz dzień, tydzień, miesiąc, 3 miesiące, 6 miesięcy i 12 miesięcy po nim. Ciśnienie wewnątrzgałkowe mierzono w lampie szczelinowej metodą tonometrii aplanacyjnej Goldmanna.
Dodatkowo u pacjentów wykonywano optyczną koherentną tomografię tylnego odcinka oka (SS-OCT, swept source optical coherence tomography) (DRI SS-OCT Triton, Topcon Inc., Tokyo, Japan) w celu oceny bezpieczeństwa zabiegu pod kątem występowania pooperacyjnego obrzęku plamki. 
Zabieg UCP był przeprowadzony przy użyciu urządzenia EyeOP $1^{\oplus}$ (Eye Tech Care, Rillieux-la-Pape, France) w znieczuleniu ogólnym dożylnym lub miejscowym okołogałkowym. Dokładniejszy opis procedury zabiegu UCP oraz urządzenia EyeOP1 ${ }^{\oplus}$ został opisany w poprzedniej publikacji [4]. W badaniu używano drugiej generacji głowicy ultradźwiękowej - sonda w kształcie pierścienia, z sześcioma piezoelektrycznymi elementami (przetwornikami) pracującymi na wysokiej częstotliwości $21 \mathrm{MHz}$. Występujące trzy rozmiary sondy $(11,12$ i $13 \mathrm{~mm})$ dopasowywane są do rozmiaru gałki ocznej w oparciu o długość gałki ocznej oraz średnicę rogówki (pomiar metodą biały do białego [WTW, white to white]). Potrzebne pomiary były wykonane przy użyciu urządzenia IOL Master 700 (Carl Zeiss, Meditec AG, Jena, Germany). W skrócie procedura polega na precyzyjnym umiejscowieniu głowicy na powierzchni oka i wytworzeniu automatycznej próżni w celu jego stabilizacji. Istotne jest idealne scentrowanie stożka w stosunku do rąbka rogówki. Może w tym pomóc zastosowanie mikroskopu operacyjnego. Po umieszczeniu w stożku sondy jest aktywowanych kolejno sześć przetworników. Czas działania każdego wynosi 8 s. Odstęp między działaniem kolejnych przetworników wynosi 20 s. Daje to ok. 3 min łącznego czasu zabiegu jednego oka. W każdej chwili chirurg może przerwać operację (ryc. 1). Zabieg jest przeprowadzany w warunkach sterylnych.

\section{RYCINA ( 1}

Procedura zabiegu ultradźwiękowej plastyki ciała rzęskowego. W warunkach sterylnych chirurg umiejscawia stożek mocujący na powierzchni oka. Po wytworzeniu próżni umieszcza się w nim sondę, wypełniając przestrzeń między sondą a powierzchnią oka roztworem BSS lub Ringera. Następnie aktywowane są kolejno przetworniki w ściśle określonych odstępach czasu.

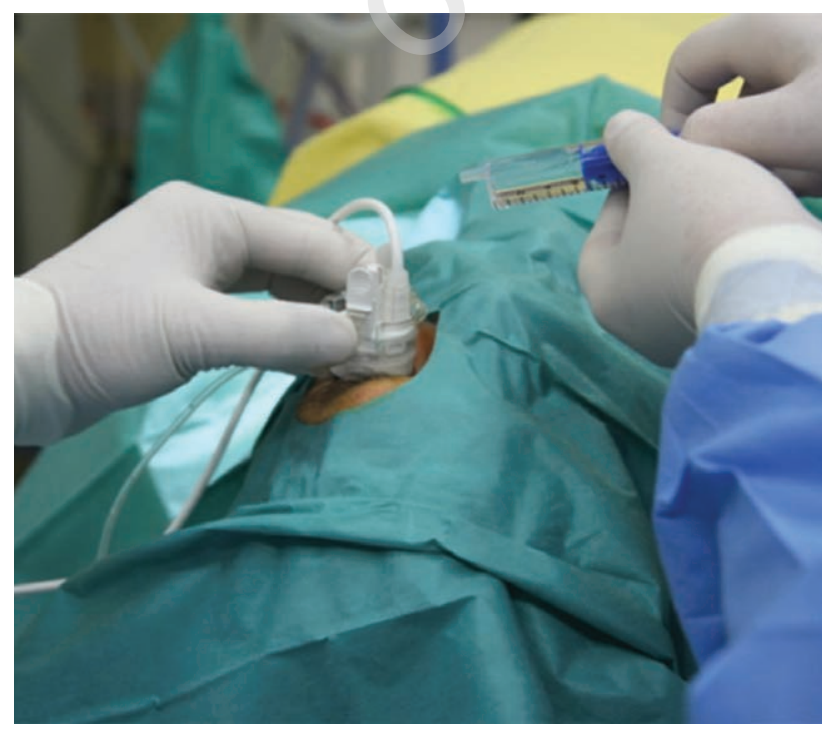

Pooperacyjna farmakoterapia obejmowała miejscowe leczenie przeciwjaskrowe w zależności od CWG. Dodatkowo po zabiegu stosowano krople oczne: deksametazon 5 razy dziennie przez 2 tygodnie, następnie 3 razy dziennie przez kolejne 2 tygodnie), ofloksacyna - 5 razy dziennie przez tydzień, atropina $1 \%-2$ razy dziennie przez tydzień. Analiza statystyczna została wykonana przy użyciu oprogramowania Statistica Software wersja 13 (TIBCO Software Inc., Palo Alto, CA). Wykorzystane zostały testy statystyczne parametryczne i nieparametryczne w zależności od typu rozkładu statystycznego danych klinicznych. Wartości $\mathrm{p}<0,05$ uznano za istotne statystycznie.

\section{WYNIKI}

Wyniki prezentowane są dla 57 pacjentów biorących udział w badaniu.

Czterech pacjentów $(7,0 \%)$ ze względu na nieuzyskanie wartości docelowych CWG zostało poddanych ponownym zabiegom przeciwjaskrowym. Trzech pacjentów (5,3\%) zostało poddanych TSCP, jeden UCP $(1,8 \%)$.

Średnie wartości CWG \pm SD (mmHg) przed zabiegiem oraz dzień, tydzień, miesiąc, 3 miesiące, 6 miesięcy i 12 miesięcy po nim wyniosły odpowiednio: $22,7 \pm 5,1,17,1 \pm 4,3,15,9 \pm$ $4,7,18,7 \pm 5,2,17,3 \pm 4,8,16,9 \pm 3,8,16,6 \pm 4,5$ (p $<0,001$ dla wszystkich wartości) (tab. 2, ryc. 2). Średnia wartość CWG została obniżona o $26,9 \% 12$ miesięcy po zabiegu w porównaniu z wartością sprzed operacji.

Według przyjętych kryteriów sukces częściowy uzyskano w przypadku $87,7 \%$ oczu, a sukces całkowity w przypadku $12,3 \%$ oczu.

Średnia liczba leków przeciwjaskrowych \pm SD przed zabiegiem oraz dzień, tydzień, miesiąc, 3 miesiące, 6 miesięcy i 12 miesięcy po nim wyniosła odpowiednio: $4,0 \pm 0,9$, $0,9 \pm 1,1,0,9 \pm 1,1,1,1 \pm 1,1,1,8 \pm 1,4,2,1 \pm 1,4,2,4 \pm 1,4$ (p < 0,001 wyniosło dla wszystkich wartości) (tab. 2, ryc. 3). Liczba leków przeciwjaskrowych przyjmowanych przez pacjentów 12 miesięcy po zabiegu UCP pokazuje rycina 4.

Średnia wartość BCVA logMAR \pm SD przed zabiegiem oraz tydzień, miesiąc, 3 miesiące, 6 miesięcy i 12 miesięcy po nim wyniosła odpowiednio: $0,37 \pm 0,46,0,47 \pm 0,45$ $(\mathrm{p}=0,003), 0,46 \pm 0,45(\mathrm{p}=0,004), 0,31 \pm 0,37(\mathrm{p}=0,151)$, $0,36 \pm 0,45(\mathrm{p}=0,880), 0,39 \pm 0,47(\mathrm{p}=0,504)$.

Obniżenie wartości CWG oraz liczby leków przeciwjaskrowych stosowanych przez pacjentów były statystycznie znamienne przez cały roczny okres obserwacji. Wartość BCVA logMAR przed zabiegiem i po nim w pierwszym miesiącu była istotna statystycznie. W kolejnych miesiącach natomiast nie stwierdzono już takiej zależności wyniki były statystycznie nieznamienne ( $\mathrm{p}>0,05)$. 


\section{Charakterystyka demograficzna pacjentów poddanych zabiegowi UCP.}

\begin{tabular}{l|c|c|c|c|c|c|c|c|c}
\multicolumn{4}{c|}{ Średnie CWG \pm SD } & Wartość $p$ & \multicolumn{2}{c|}{ Średnia liczba leków przeciwjaskrowych \pm SD } & Wartość $p$ & $\begin{array}{c}\text { Obniżenie CGW } \\
\%\end{array}$ \\
\hline Przed operacją & 22,7 & \pm & 5,1 & & 4,0 & \pm & 0,9 & & - \\
\hline 1. dzień & 17,1 & \pm & 4,3 & $\mathrm{p}<0,001$ & 0,9 & \pm & 1,1 & $\mathrm{p}<0,001$ & 24,7 \\
\hline 1. tydzień & 15,9 & \pm & 4,7 & $\mathrm{p}<0,001$ & 0,9 & \pm & 1,1 & $\mathrm{p}<0,001$ & 29,8 \\
\hline 1. miesiąc & 18,7 & \pm & 5,2 & $\mathrm{p}<0,001$ & 1,1 & \pm & 1,1 & $\mathrm{p}<0,001$ & 17,4 \\
\hline 3. miesiąc & 17,3 & \pm & 4,8 & $\mathrm{p}<0,001$ & 1,8 & \pm & 1,4 & $\mathrm{p}<0,001$ & 23,9 \\
\hline 6. miesiąc & 16,9 & \pm & 3,8 & $\mathrm{p}<0,001$ & 2,1 & \pm & 1,4 & $\mathrm{p}<0,001$ & 25,3 \\
\hline 12. miesiąc & 16,6 & \pm & 4,5 & $\mathrm{p}<0,001$ & 2,4 & \pm & 1,4 & $\mathrm{p}<0,001$ & 26,9
\end{tabular}

\section{Średnie CWG przed zabiegiem UPC i po nim w rocznym okresie obserwacji.}
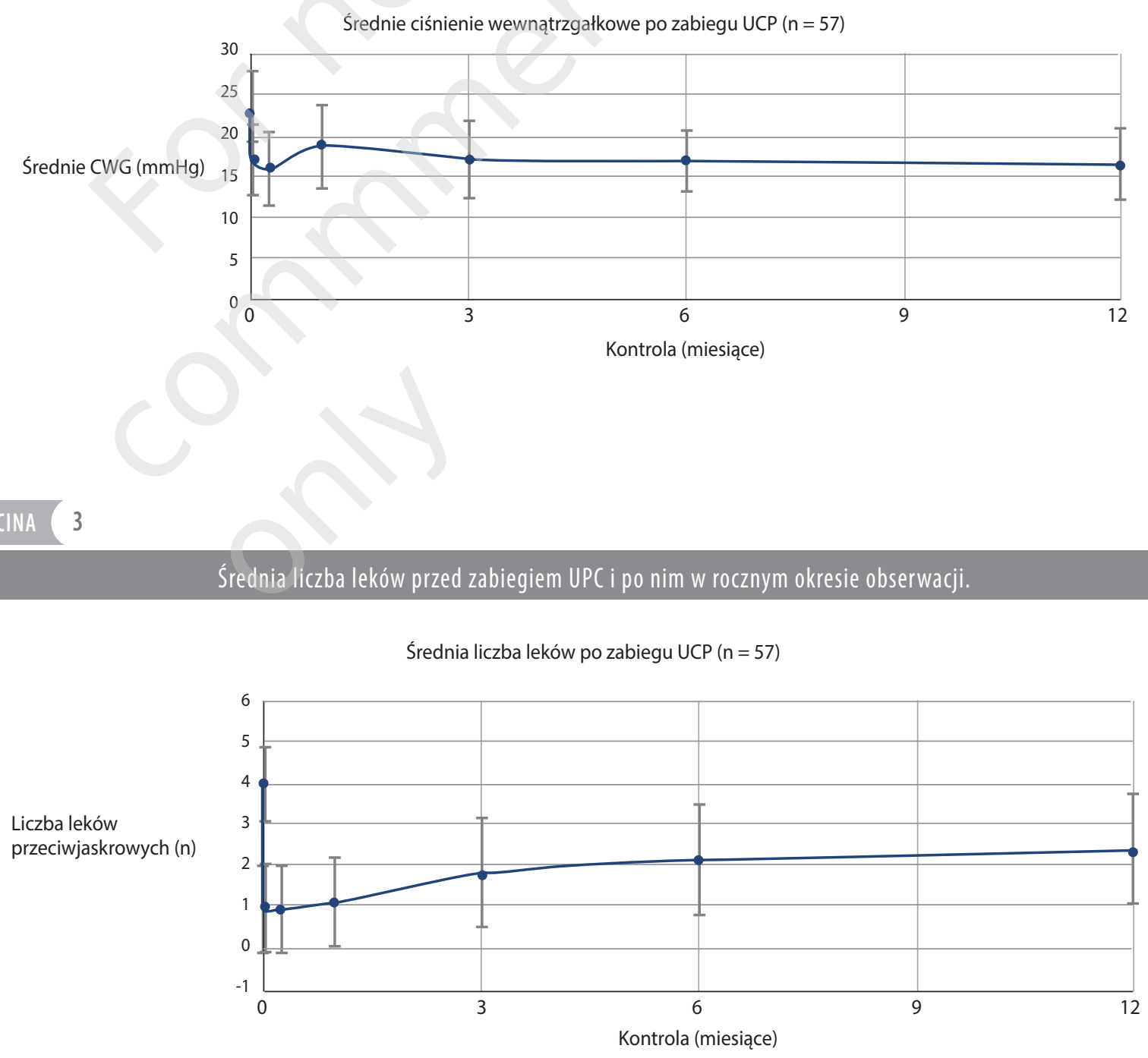


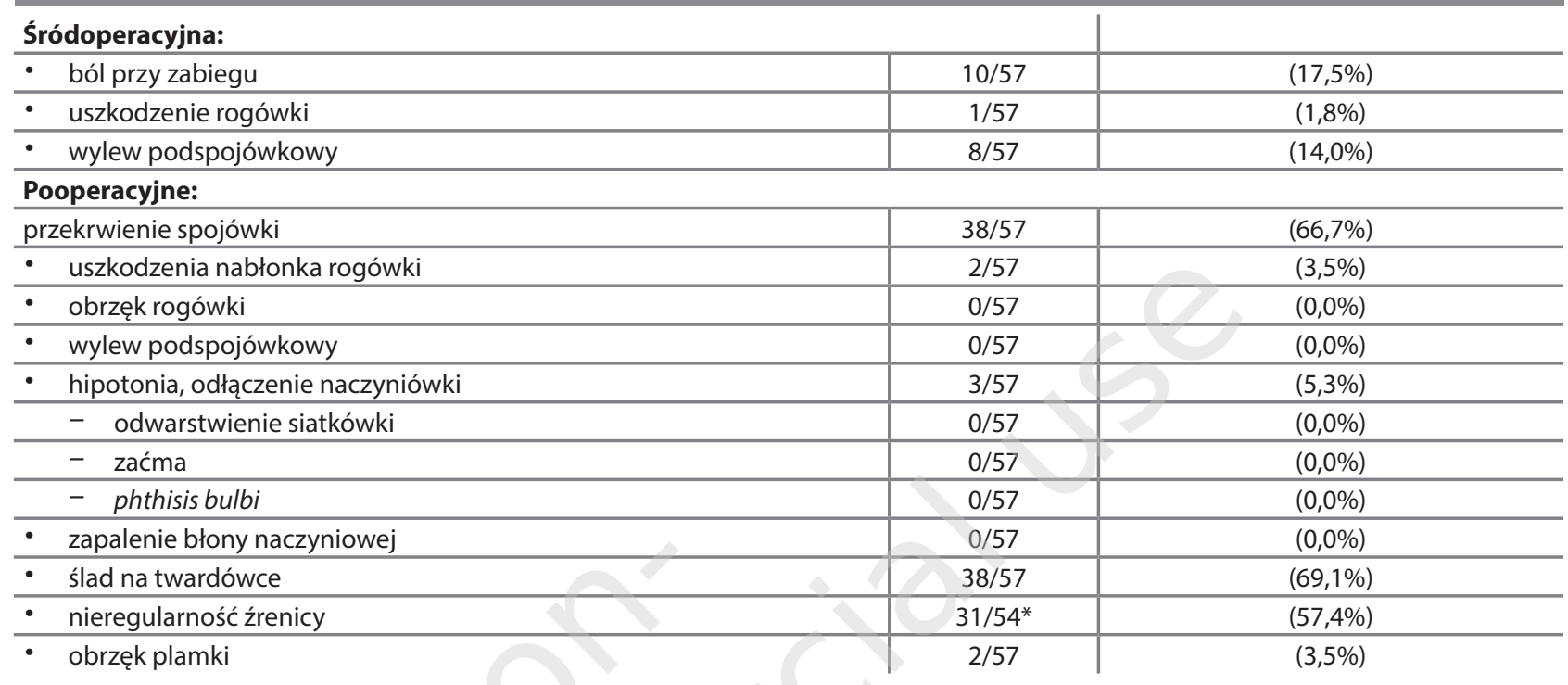

* Nieregularność źrenicy zaobserwowano u 31 z 54 pacjentów. U pozostałych trzech pacjentów z grupy badanej nie była możliwa ocena źrenicy z powodu jej nieregularności przed zabiegiem.

\section{RYCINA 4}

Liczba leków przeciwjaskrowych przyjmowanych przez pacjentów 12 miesięcy po zabiegu UCP oraz procent pozostałych pacjentów poddanych dodatkowemu zabiegowi przeciwjaskrowemu.

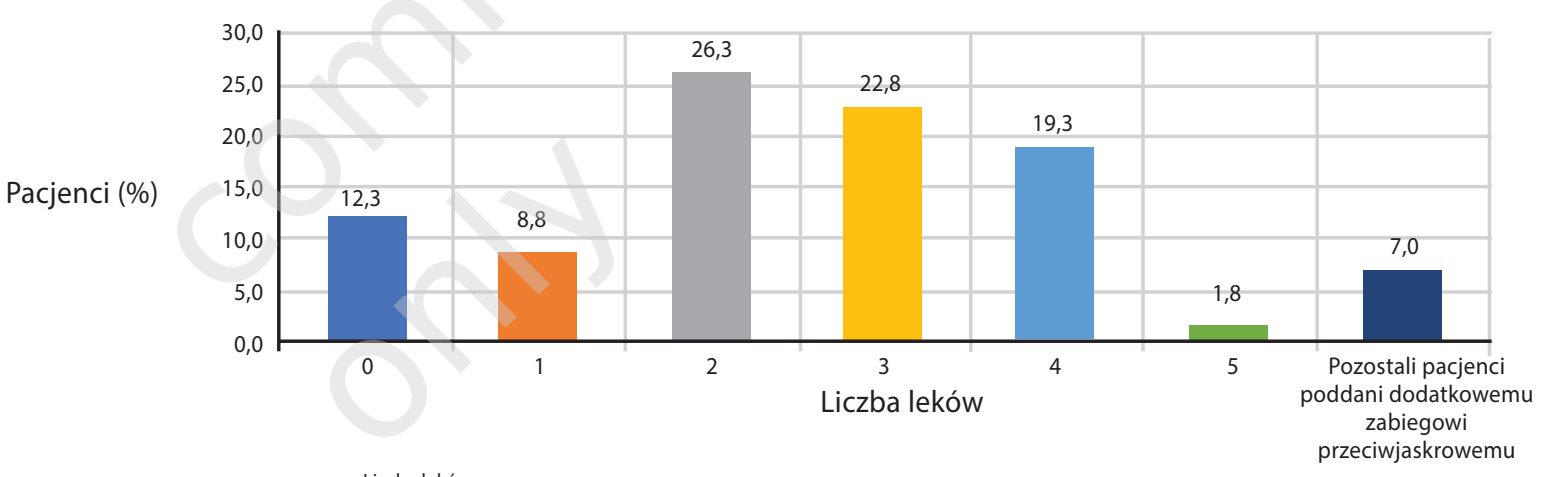

Liczba leków

\begin{tabular}{ll|l|l|l|l|l|l}
0 & 1 & 2 & 3 & 4 & 5
\end{tabular} Pozostali pacjenci poddani dodatkowemu zabiegowi przeciwjaskrowemu

Powikłania śródoperacyjne i pooperacyjne przedstawiono $\mathrm{w}$ tabeli 3 . U trzech pacjentów zaobserwowano odłączenie naczyniówki (5,3\%). U dwóch pacjentów stwierdzono cystoidalny obrzęk plamki (3,5\%). Innych poważnych powikłań śródoperacyjnych i pooperacyjnych nie odnotowano.

\section{OMÓWIENIE}

Obniżenie CWG jest jedyną skuteczną i udowodnioną metodą terapii jaskry $[5,6]$. Można to uzyskać poprzez poprawienie odpływu cieczy wodnistej metodami farmakologicznymi i chirurgicznymi i/lub ograniczenie jej produkcji. Mechanizm destrukcyjny fotokoagulacji, krioterapii czy ultradźwięków uszkadza nabłonek niebarwnikowy ciała rzęskowego, powodując zmniejszenie produkcji cieczy wodnistej. Bardzo skuteczną i obecnie najpopularniejszą metodą tego typu zabiegu jest TSCP. Metoda ta jest stosowana głównie w jaskrze opornej, gdy wcześniejsze leczenie zachowawcze lub chirurgiczne w postaci zabiegów filtracyjnych czy setonowych nie dało oczekiwanych rezultatów [7]. Wadę tego zabiegu stanowi ograniczona wybiórczość 
w stosunku do celowanej tkanki. Energia lasera jest przede wszystkim absorbowana przez pigmentowane tkanki, co może powodować uszkodzenie sąsiadujących tkanek, tęczówki czy naczyniówki. Trudny do przewidzenia jest również efekt w stosunku do zastosowanej dawki.

Najczęstszymi powikłaniami TSCP są: ból podczas zabiegu i po nim, przekrwienie i oparzenia spojówki, ścieńczenie twardówki czy zapalenie przedniego odcinka błony naczyniowej [8-11], rzadszymi zaś: hipotonia, odłączenie naczyniówki, zapalenie naczyniówki, odwarstwienie siatkówki, zanik gałki ocznej [12].

Cyklodestrukcja endoskopowa (ECP, endoscopic cyclophotocoagulation) jest metodą bezpieczniejszą i bardziej selektywną niż TSCP [13, 14], lecz głównie stosuje się ją u pacjentów z łagodną lub umiarkowaną jaskrą oraz współistniejącą zaćmą $[15,16]$. Najczęstszymi powikłaniami tej metody są: zwyżki CWG, zwiększony odczyn zapalny (w porównaniu z fakoemulsyfikacją zaćmy bez ECP) czy dyslokacja sztucznej soczewki na skutek naruszenia aparatu wieszadłowego [17].

Najważniejszą zaletą ultradźwięków o wysokiej intensywności (HIFU, high-intensity focused ultrasound), stosowanych w metodzie UCP, jest możliwość skupienia energii przez nieprzezroczyste ośrodki, bez niekontrolowanej absorpcji, na pożądanej głębokości oraz powierzchni [3]. Ogranicza to uszkodzenie sąsiadujących tkanek oraz powoduje, że ilość dostarczonego ciepła do tkanki nie zależy od jej właściwości, np. od pigmentacji, która w przypadku ciała rzęskowego może się znacznie różnić osobniczo [1, 2, 19]. Obniżenie wartości CWG oraz liczby leków przeciwjaskrowych stosowanych przez pacjentów było statystycznie znamienne przez caly roczny okres obserwacji. Średnia wartość CWG została obniżona o $26,9 \%$ na ostatniej wizycie w porównaniu z wartością sprzed operacji, co jest porównywalnym wynikiem do wyników badań opublikowanych do tej pory [3, 20-22]. W rocznej obserwacji tylko u 12,3\% pacjentów nie udało się uzyskać docelowego CWG.

Dotychczas opublikowane prace naukowe donoszą o niskiej skuteczności UCP w obniżeniu CWG w przypadku jaskry neowaskularnej.

Różnica wartości BCVA logMAR przed zabiegiem i po nim w 1 . miesiącu była istotna statystycznie, jednakże było to spowodowane mydriatykami, jakie pacjenci otrzymywali po operacji. W kolejnych miesiącach nie stwierdzono już takiej zależności - wyniki były statystycznie nieznamienne. Dostępne publikacje pokazują takie same wyniki - po zabiegu UCP autorzy nie stwierdzają pogorszenia ostrości wzroku [20-23].

Oprócz pojedynczych przypadków przejściowego odłączenia naczyniówki i obrzęku plamki nie odnotowano innych poważnych powikłań śródoperacyjnych i pooperacyjnych, takich jak: odwarstwienie siatkówki, zaćma czy zanik gałki ocznej. Częstość stwierdzonych powikłań była zbliżona do częstości obserwowanej w badaniach opublikowanych dotychczas [20-23]. U obu pacjentów z pooperacyjnym obrzękiem plamki na powierzchni siatkówki stwierdzono błonę nasiatkówkową. Przez 2 miesiące stosowano bromfenak w kroplach ocznych 2 razy dziennie, czego skutkiem było wycofanie się obrzęku (ryc. 5). U pacjentów ze stwierdzoną przedoperacyjnie błoną nasiatkówkową należy zastanowić się nad profilaktycznym stosowaniem niesteroidowych leków przeciwzapalnych w postaci kropli ocznych w celu profilaktyki pooperacyjnego obrzęku plamki.

W badaniu w lampie szczelinowej zaobserwowano nieregularność źrenicy u 31 z 54 pacjentów $(57,4 \%)$. U pozostałych trzech pacjentów $\mathrm{z}$ grupy badanej ocena źrenicy nie była możliwa z powodu jej nieregularności przed zabiegiem. Nieregularność oceniano w lampie szczelinowej.

\section{RYCINA 5}

Obrzęk plamki po zabiegu UCP. Skan SS-OCT plamki jednego z pacjentów z pooperacyjnym obrzękiem plamki. A. Przed zabiegiem. B. Po zabiegu. C. Po 2-miesięcznym okresie stosowania miejscowo bromfenaku.

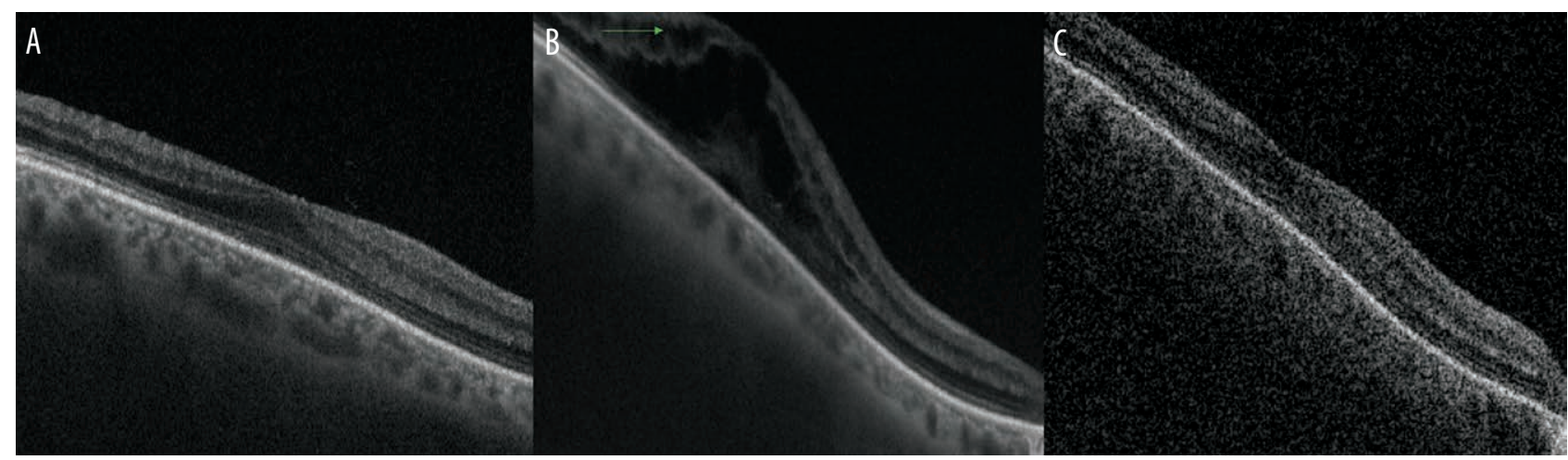


Według Sousy i wsp. [24] nieregularność źrenicy po zabiegu UCP może mieć dwie przyczyny. Pierwszą z nich jest to, że chociaż urządzenie EyeOP $1^{\oplus}$ oszczędza okolice twardówki na godzinie 3 i 9, energia ultradźwiękowa wpływa na niewielkie pozazwojowe nerwy przywspółczulne rzęskowe krótkie, które przebiegają okrężnie i przeszywają twardówkę, dochodząc do mięśnia rzęskowego. Drugą przyczyną mogą być zmienności anatomiczne. Wielkość głowicy jest dobierana według parametrów biometrycznych oka, lecz nawet najmniejszy wpływ na obwodową część tęczówki może spowodować zmianę jej kształtu w tym miejscu. W innym badaniu przeprowadzonym przez nasz ośrodek, pomimo widocznej nieregularności w kształcie źrenicy, nie stwierdzono istotnej statystycznie różnicy w jej najszerszym wymiarze [25]. Biorąc pod uwagę dostępne doniesienia literaturowe na temat tego zagadnienia, wydaje się, że nieregularność w kształcie źrenicy nie ma większej implikacji klinicznej. Jednakże powinno się przeprowadzić bardziej kompleksowe badania w celu potwierdzenia tej tezy. W grupie badanej stwierdzono występowanie impaktów na twardówce w miejscu, w którym była dostarczana energia ultradźwiękowa. Częstość występowania wyniosła 69,1\%. W badaniu w lampie szczelinowej impakty na twardówce wyglądają jak jej ścieńczenia - ciemniejsze owalne przebarwienia. Natomiast w innym badaniu przeprowadzonym przez nasz ośrodek w celu dokładniejszej oceny miejsca aplikacji energii podczas zabiegu UCP w skanach OCT nie stwierdzono ścieńczenia, tylko przejściowe pogrubienie twardówki. Zmierzone wartości grubości twardówki w ciągu 18 miesięcy wróciły do wartości sprzed zabiegu [26].
Podsumowując, średnie CWG zostało obniżone o 26,9\% i oprócz pojedynczych przypadków odłączenia naczyniówki czy obrzęku plamki nie zaobserwowano poważniejszych powikłań. Nasze wyniki potwierdzają skuteczność i bezpieczeństwo zabiegu UCP, jakie publikowano do tej pory. Przeprowadzenie 2-letnich obserwacji będzie mogło pokazać, jak kształtuje się skuteczność w dłuższym okresie po zabiegu UCP. Przy niektórych wadach obecnie stosowanych metod cyklodestrukcyjnych słuszne wydaje się poszukiwanie nowych rozwiązań mających na celu poprawienie bezpieczeństwa oraz skuteczności tego typu zabiegów.

\section{PODSUMOWANIE}

Ultradźwiękowa plastyka ciała rzęskowego jest skuteczną i bezpieczną metodą w leczeniu jaskry opornej w średnioterminowej obserwacji. Dalsze badania na większej grupie pacjentów oraz dłuższym okresie obserwacji powinny być prowadzone.

\section{Źródto rycin: Wszystkie ryciny pochodza z materiatów własnych autora/autorów.}

\section{Projekt pracy zostat zaakceptowany przez Komisje Bioetyczna przy Śląsim Uniwersytecie Medycznym (nr decyzji KNW/0022/KB1/78/18).}

The study design was approved by the Bioethics Committee of the Medical University of Silesia (no. KNW/0022/KB1/78/18).

\section{ORCID}

Bartłomiej Bolek - ID - http://orcid.org/0000-0002-3205-6864

Edward Wylęgala - ID - http://orcid.org/0000-0002-6707-5790

\section{Piśmiennictwo}

1. Aptel F, Charrel T, Palazzi X et al. Histologic effects of a new device for High-Intensity focused Ultrasound Cyclocoagulation. Investig Ophthalmol Vis Sci 2010; 51: 5092-8.

2. Charrel T, Aptel F, Birer A et al. Development of a Miniaturized HIFU Device for Glaucoma Treatment With Conformal Coagulation of the Ciliary Bodies. Ultrasound MedBiol. 2011; 37: 742-54.

3. Aptel F, Charrel T, Lafon C et al. Miniaturized high-intensity focused ultrasound device in patients with glaucoma: A clinical pilot study. Investig Ophthalmol Vis Sci. 2011; 52: 8747-53.

4. Bolek B, Ulfik KI, Dembski M et al. Ultradźwiękowa plastyka ciała rzęskowego - technika zabiegu i wstępne wyniki. Mag Lek Okulisty. 2017; 11: 138-48.

5. Ocular Hypertension Treatment Study: A randomized trial determines that topical ocular hypotensive medication delays or prevents the onset of primary open-angle glaucoma. Arch Ophthalmol. 2002; 120: 701-13.

6. Heijl A, Leske MC, Bengtsson B et al. Reduction of intraocular pressure and glaucoma progression: Results from the Early Manifest Glaucoma. Trial Arch Ophthalmol. 2002; 120: 1268-79. 
7. Jankowska-Szmul J, Dobrowolski D, Wylegala E. CO2 laser-assisted sclerectomy surgery compared with trabeculectomy in primary open-angle glaucoma and exfoliative glaucoma. A 1-year follow-up. Acta Ophthalmol. 2018; 96: e582-e91.

8. Vernon SA, Koppens JM, Menon GJ et al. Diode laser cycloablation in adult glaucoma: Long-term results of a standard protocol and review of current literature. Clin Exp Ophthalmol. 2006; 34(5): 411-20.

9. Walland MJ. Diode laser cyclophotocoagulation: Longer term follow up of a standardized treatment protocol. Clin Exp Ophthalmol. 2000; 28: 263-7.

10. Frezzotti P, Mittica V, Martone $G$ et al. Longterm follow-up of diode laser transscleral cyclophotocoagulation in the treatment of refractory glaucoma. Acta Ophthalmol. 2010; 88: 150-5.

11. Pucci V, Tappainer F, Borin S et al. Long-term follow-up after transscleral diode laser photocoagulation in refractory glaucoma. Ophthalmologica. 2003; 217: 279-83.

12. Tan AM, Chockalingam M, Aquino MC et al. Micropulse transscleral diode laser cyclophotocoagulation in the treatment of refractory glaucoma. Clin Exp Ophthalmol. 2010; 38: 266-72.

13. Pantcheva MB, Kahook MY, Schuman JS et al. Comparison of acute structural and histopathological changes in human autopsy eyes after endoscopic cyclophotocoagulation and trans-scleral cyclophotocoagulation. Br J Ophthalmol. 2007; 91: 248-52.

14. Lin SC, Chen MJ, Lin MS et al. Vascular effects on ciliary tissue from endoscopic versus trans-scleral cyclophotocoagulation. Br J Ophthalmol. 2006; 90: 496-500.

15. Berke S, Cohen A, Sturm R et al. Endoscopic Cyclophotocoagulation (Ecp) and Phacoemulsification in the Treatment of Medically Controlled Primary Open-Angle Glaucoma. J Glaucoma. 2000; 9: 129.

16. Siegel MJ, Boling WS, Faridi OS et al. Combined endoscopic cyclophotocoagulation and phacoemulsification versus phacoemulsification alone in the treatment of mild to moderate glaucoma. Clin Exp Ophthalmol. 2015; 43: 531-9.

17. Noecker RJ, Kahook MY, Berke SJ et al. Uncontrolled intraocular pressure after endoscopic cyclophotocoagulation. J Glaucoma. 2008; 17(3): 250-1.

18. Noecker RJ, Group ECS. Complications of Endoscopic Cyclophotocoagulation. The ASCRS Symp Cataract IOL Refract Surgery; San Diego, CA. 2007; 24(4): 177-82.

19. Aptel F, Lafon C. Therapeutic applications of ultrasound in ophthalmology. Int J Hyperth. 2012; 28: 405-18.

20. Aptel F, Denis P, Rouland JF et al. Multicenter clinical trial of high-intensity focused ultrasound treatment in glaucoma patients without previous filtering surgery. Acta Ophthalmol. 2016; 94: 268-77.

21. Deb-Joardar N, Reddy K. Application of high intensity focused ultrasound for treatment of open-angle glaucoma in Indian patients. Indian J Ophthalmol. 2018; 66: 517-23.

22. Giannaccare G, Vagge A, Sebastiani S et al. Ultrasound Cyclo-Plasty in Patients with Glaucoma: 1-Year Results from a Multicentre Prospective Study. Ophthalmic Res. 2019; 61: 137-42.

23. Denis P, Aptel F, Rouland JF et al. Cyclocoagulation of the ciliary bodies by high-intensity focused ultrasound: A 12-month multicenter study. Investig. Ophthalmol. Vis Sci. 2015; 56: 1089-96. http://iovs.arvojournals.org/Article.aspx?doi=10.1167/iovs.14-14973.

24. Sousa DC, Ferreira NP, Marques-Neves C et al. High-intensity focused ultrasound cycloplasty: Analysis of pupil dynamics. J Curr Glaucoma Pract. 2018; 12: 102-6.

25. Bolek B, Wylegala A, Mazur R et al. Pupil irregularity after ultrasound ciliary plasty in glaucoma treatment. Acta Ophthalmol. 2019; 97: S263.

26. Bolek B, Wylęgała A, Wylęgała. Assessment of Scleral and Conjunctival Thickness of the Eye after Ultrasound Ciliary Plasty. J Ophthalmol. 2020; 2020: 9659014. https://doi.org/10.1155/2020/9659014.

Wkład autorów:

Barttomiej Bolek: koncepcja, zbieranie danych, analiza danych, wizualizacja, pisanie manuskryptu; Edward Wylęgała: koncepcja, analiza danych, nadzór, pisanie manuskryptu.

Konflikt interesów:

Nie występuje.

Finansowanie:

Nie występuje.

Etyka:

Treści przedstawione w artykule są zgodne z zasadami Deklaracji Helsińskiej, dyrektywami EU oraz ujednoliconymi wymaganiami dla czasopism biomedycznych.
Authors' contributions:

Bartłomiej Bolek: conception, data collection, data analysis, visualization, manuscript writing; Edward Wylęgała: conception, data analysis, supervision, manuscript writing. Conflict of interest:

None.

Financial support:

None.

Ethics:

The content presented in the article complies with the principles of the Helsinki Declaration, EU directives and harmonized requirements for biomedical journals. 